\title{
BULGARSKI CAR PIOTR I JEGO ŻONA MARIA LEKAPENA W LATOPISIE HELLEŃSKIM I RZYMSKIM DRUGIEJ REDAKCJI ${ }^{1}$
}

\author{
PETER OF BULGARIA AND HIS WIFE MARIA LEKAPENE \\ IN THE SECOND VERSION OF THE HELLENIC AND ROMAN CHRONICLE
}

\begin{abstract}
The sequence concerning the reign of Peter and Maria Lekapene as well as the Byzantine-Bulgarian relations between 927 and 969 can be found in the second version of the Hellenic and Roman Chronicle. It is a vast historiographical work, whose authors attempted to demonstrate the history of medieval Rus against the broad background of universal history, drawing on the sources of Byzantine provenance known in Slavonic translation (mainly the chronicles of John Malalas and George Hamartolus). Given the fact that the Hellenic and Roman Chronicle does not contain information about the capture of Constantinople by the Ottoman Turks, the year 1453 is considered the terminus ante quem for the second version of the said chronicle, which is of interest to us here. Its oldest preserved copies come from the mid-fifteenth century. The passages about Maria and Peter are extensive. They include about six columns of text written in semi-uncial in the most representative copy of the second version of the Hellenic and Roman Chronicle, i.e. manuscript БАН, 33.8.13, which is dated to the last quarter of the fifteenth century. Reading them allows one to ascertain that they constitute only a reworded version of the Slavic translation of the relevant passages of the B-version of the Georgius Monachus Continuatus. The content of the Byzantine source is quoted here in full without any abbreviations or author's additions. The differences between the text of БАН, 33.8.13 and the text of РГБ, собр. Ундольского [Ф. 310], № 1289 - constituting the basis for editing the translation of the Georgius Monachus Continuatus of the B-version - are limited only to the stylistic and editorial level, except for the changes resulting most probably from the copyist misunderstanding the meaning of the original.
\end{abstract}

Keywords: Old Russian literature, Hellenic and Roman Chronicle, Peter, Maria Lekapene, Byzantine-Bulgarian relations

*Wydział Filologiczny UŁ, Katedra Filologii Słowiańskiej, ul. Pomorska 171/173, 90-236 Łódź; zofia.brzozowska@uni.lodz.pl.

${ }^{1}$ Niniejszy artykuł powstał w ramach projektu sfinansowanego ze środków Narodowego Centrum Nauki, przyznanych na podstawie decyzji nr DEC-2014/14/M/HS3/00758 (Państwo butgarskie w latach 927-969. Epoka cara Piotra I Pobożnego). 
Latopis helleński $i$ rzymski jest niewątpliwie unikalnym zabytkiem średniowiecznej historiografii ruskiej. Jego anonimowi autorzy podjęli się bowiem zgoła niezwykłego zadania - zapragnęli ukazać początki państwa Rurykowiczów na szerokim tle historii powszechnej. Swą narrację rozpoczęli zatem, zgodnie z rozpowszechnioną w literaturze bizantyńskiej tradycją, od stworzenia świata, a następnie zaprezentowali obszerny skrót wydarzeń starotestamentowych i opis podbojów Aleksandra Macedońskiego. Szczególnie wiele miejsca poświęcili też dziejom Rzymu, szkicując okoliczności powstania miasta nad Tybrem i śledząc jego dalszą historię: zarówno z epoki, w której władali nim królowie, jak i z okresu republiki, pryncypatu i dominatu. Twórców latopisu interesowały również dzieje „chrześcijańskiego cesarstwa" ze stolicą w Konstantynopolu - jego początki wiązali, rzecz jasna, z panowaniem Konstantyna I Wielkiego (306-337), założyciela metropolii nad Bosforem, a także - pierwszego władcy rzymskiego, który zwrócił się ku nowej religii. Co ciekawe, w dość systematyczny wykład dziejów Bizancjum, doprowadzony do czasu rządów Romana I Lekapena (919-944), współczesnego księciu kijowskiemu Igorowi (912-945), wpleciono wiele wzmianek na temat państwa bułgarskiego i władających nim osób. Wśród nich na szczególną uwagę zasługuje postać Symeona I Wielkiego (893-927) oraz jego syna Piotra (927-969), ożenionego z Marią Lekapeną (Творогов 1989, s. 18; Творогов 1999, s. I).

Autorzy Latopisu helleńskiego i rzymskiego bazowali zarówno na zabytkach staroruskiej historiografii, jak i na źródłach bizantyńskich, przede wszystkim na przekazie kroniki Jana Malalasa oraz dzieła Jerzego Hamartolosa (Mnicha) wraz z jego anonimową kontynuacją (Лихачев 1948, s. 104; Клосс 1972, s. 371-375; Творогов 1975, s. 141-143; Творогов 1989, s. 18-19; Творогов 1999, s. I-II; Творогов 2001, s. 64; Бобров 2004, s. 86-87; Колесов 2004, s. 91; Вилкул 2015, s. 372). Tekstów tych nie czytali zapewne w oryginale greckim, poprzestając na ich przekładach na język staro-cerkiewno-słowiański, wykonanych najprawdopodobniej w Bułgarii u schyłku X w., lub też w początkach następnego stulecia (Мещерский 1978, s. 88-89; Творогов 1989, s. 18-19; Творогов 1999, s. IV; Творогов 2001, s. 64-72). W niektórych partiach narracji interesującego nas tu źródła odnaleźć można wyraźne zapożyczenia i dosłowne przeniesienia z tekstów słowiańskich thumaczeń obu wspomnianych kronik.

Latopis helleński i rzymski zachował się do naszych dni w dwóch wariantach. Pierwszą redakcję zwodu reprezentują cztery odpisy: ГИМ, Синод. собр., № 280 (XVI w.); ГИМ, собр. Уварова, № 10/1334 (XVI w.); РНБ, собр. Погодина, № 1437 (XVI-wieczny, zawierający tylko połowę tekstu zabytku) oraz БАН, 45.10 .6 - fragmentaryczny, ze schyłku XV w. (Клосс 1972, s. 379; Творогов 1989, s. 18).

Druga redakcja Latopisu helleńskiego i rzymskiego musiała powstać w pierwszej połowie XV stulecia (Бобров 2004, s. 89; Колесов 2004, s. 91-92; Анисимова 2009, s. 31). Wykład dziejów powszechnych, zakończony w pierwotnej wersji źródła na roku 948, został tu bowiem uzupełniony o rejestr cesarzy bizantyńskich i lat 
ich panowania, obejmujący okres od rządów Nikefora II Fokasa (963-969) do epoki Manuela II Paleologa (1391-1425). W sekwencję tę została też włączona obszerna opowieść o zajęciu Konstantynopola przez uczestników czwartej wyprawy krzyżowej w 1204 r. (zaczerpnięta najprawdopodobniej z Latopisu nowogrodzkiego pierwszego), a także dwie krótkie narracje na temat przedmiotów kultu, znajdujących się w bizantyńskiej stolicy: ikony Bogurodzicy Hodegetrii oraz szaty Matki Bożej, przechowywanej w kościele w Blachernach (Лихачев 1948, s. 104; Клосс 1972, s. 375; Творогов 1975, s. 147; Творогов 1989, s. 18-19; Бобров 2004, s. 87). Autorzy zwodu nie wspomnieli natomiast o zdobyciu Konstantynopola przez Turków Osmańskich w 1453 roku. Można zatem przyjąć, iż prace nad drugą redakcją analizowanego zabytku zakończono przed tym wydarzeniem (Клосс 1972, s. 375-376; Творогов 1975, s. 159; Творогов 1989, s. 18; Анисимова 2009, s. 31).

Z XV stulecia pochodzi też kilka odpisów, reprezentujących drugą redakcję tekstu: БАН, 33.8 .13 (niepełny, pozbawiony początkowej partii, z ostatniej tercji XV w.); РГБ, собр. Пискарева, № 162 (1485 r.); rękopis z końca XV stulecia, rozdzielony obecnie na dwie części (1. РНБ, Кир.-Белоз. собр., № 1/6; 2. ГИМ, Синод. собр., № 86); ГИМ, Чуд. собр., № 51/353 (ze schyłku XV w.); РНБ, F.IV.91 (z końca XV w.). Inne są późniejsze: БАН, Арханг. собр., C 18 (z przełomu XV i XVI w.); РНБ, Соф. собр., № 1520 (fragmentaryczny, XVI w.); РНБ, собр. ОЛДП, F.33 (XVI w.); РГБ, собр. Егорова, № 867 (z połowy XVI w.); СПб. ГУ, НБ, № 108 (z początku XVII w.); РГБ, Калуж. собр. (Ф. 738), № 104 (z drugiej ćwierci XVII w., fragmentaryczny) oraz РГБ, собр. Ундольского, № 720 - XVI-wieczny, fragmentaryczny, zawierający bardzo skażoną wersję tekstu (Лихачев 1948, s. 102-103; Клосс 1972, s. 370; Творогов 1989, s. 19; Творогов 1999, s. II-III, VI-XII; Творогов 2001, s. 57-64; Рыков 2004, s. 72).

Fragmenty Latopisu helleńskiego i rzymskiego drugiej redakcji, dotyczące Marii Lekapeny i Piotra są obszerne. Obejmują około sześciu kolumn tekstu półustawem w najbardziej reprezentacyjnym odpisie zabytku, tj. rękopisie БАН, 33.8.13, datowanym na ostatnią tercję XV w. (fol. 287d-288d, 290a-290b, 290d). Ich lektura pozwala jednak stwierdzić, że stanowią jedynie przeredagowaną wersję staro-cerkiewno-słowiańskiego tłumaczenia stosownych passusów Kontynuacji Jerzego Mnicha, tzw. wersji B.

Należy tu poczynić kilka wyjaśnień terminologicznych. Kontynuacja Jerzego Mnicha jest anonimowym utworem historiograficznym, powstałym w X stuleciu. Prezentuje on opis wydarzeń od roku 842, tj. od momentu, w którym kończy się właściwa narracja Hamartolosa (Каждан 1959, s. 125; Swoboda 1965, s. 468; Wasilewski 1971, s. 62). W średniowiecznej tradycji rękopiśmiennej nie zaznaczano rozróżnienia na właściwy tekst autorstwa Jerzego Mnicha i jego anonimową kontynuację, traktując oba zabytki jako jeden utwór. Co więcej, fragmenty Konty- 
nuacji, poświęcone Marii i Piotrowi, są identyczne z analogicznymi passusami w kronice Symeona Logotety i Magistra. Utwór ten znany jest w dwóch redakcjach: redakcja A, starsza, spisana przed 863 r., prezentuje opis wydarzeń do roku 948, tj. śmierci Romana I Lekapena. Późniejsza redakcja B zawiera poszerzony o dodatkowe szczegóły wykład dziejów Bizancjum, doprowadzony do roku 963. Ze starszą redakcją kroniki Symeona Logotety jest zbieżny przekaz Kontynuacji Jerzego Mnicha redakcji A, z młodszą zaś - jej wariant B (Каждан 1959, s. 128-132; Swoboda 1965, s. 468; Swoboda 1975, s. 506-507; Treadgold 1979, s. 160; Markopoulos 1983, s. 279-284). W niektórych rękopisach przypisuje się Symeonowi Logotecie autorstwo Kontynuacji (Каждан 1959, s. 127). Co więcej, z tekstu redakcji B Kontynuacji Jerzego Mnicha vel kroniki Symeona Logotety korzystał również anonimowy autor pierwszej części księgi VI Kontynuacji Teofanesa.

Kontynuacja Jerzego Mnicha lub odpowiadające jej partie kroniki Symeona Logotety zostały przetłumaczone na język staro-cerkiewno-słowiański niezwykle wcześnie. Podstawą przekładu była młodsza, poszerzona redakcja zwodu (B) (Kaждан 1959, s. 126; Swoboda 1965, s. 468). Co więcej, interesujący nas tu utwór historiograficzny został przetłumaczony jako immanentna część kroniki Jerzego Mnicha (Hamartolosa) i odtąd był za nią w piśmiennictwie słowiańskim uważany. Miejsce i czas powstania najstarszego przekładu kroniki Jerzego Mnicha oraz jej kontynuacji jest zagadnieniem posiadającym olbrzymią literaturę przedmiotu, której przedstawienie wykracza poza ramy niniejszego studium (Творогов 1987, s. 469-470; Матвеенко, Щеголева 2000, s. 532-543). Podsumowując dotychczasową dyskusję, można stwierdzić, iż większość badaczy jest zdania, że tłumaczenie to zostało wykonane w Bułgarii pod koniec X lub na początku XI w. (a zatem rychło po powstaniu wariantu B Kontynuacji), następnie zaś zostało przewiezione na Ruś, gdzie poddano je dalszym pracom redaktorskim (Мещерский 1978, s. 78-79; Творогов 1987, s. 468-469). Niektórzy uczeni (np. Ludmiła Gorina) utrzymują, że kronika Jerzego Mnicha oraz jej kontynuacja, zawierająca opis wydarzeń z X w., przeniknęła do piśmiennictwa ruskiego za pośrednictwem pewnego, niezachowanego do naszych dni, bułgarskiego tekstu historiograficznego, tzw. Chronografu bułgarskiego, który trafił na Ruś po 1018 r. (Горина 2005, s. 80-85). Istnieją również tezy o staroruskiej proweniencji najstarszego słowiańskiego przekładu kroniki Hamartolosa (Матвеенко, Щеголева 2000, s. 6; Анисимова 2009, s. 28).

Zachował się on w kilkunastu odpisach, reprezentujących dwa warianty tekstu. Istnieją cztery rękopisy zawierające wcześniejszą redakcję słowiańskiego tłumaczenia utworu Jerzego Mnicha: najstarszy z nich datowany jest na początek XIV w. (РГБ, Троицкое собр. Ф. 173/I [МДА], № 100), pozostałe na XIV-XVI wiek. Odpisy starszej redakcji przekładu są jednak nieprzydatne dla naszych badań, gdyż tekst kroniki Hamartolosa jest w tym wariancie doprowadzony zaledwie do $553 \mathrm{r}$. (Творогов 1975, s. 12; Творогов 1987, s. 469; Матвеенко і Щеголева 2000, s. 8-9; Анисимова 2009, s. 41-70, 83-88, 124-131, 211-222). Młodsza redakcja tekstu, zależna tekstologicznie od pierwotnej, zachowała się natomiast w kilkunastu 
odpisach całościowych i kilku fragmentarycznych, pochodzących z XV-XVII wieku. Za najbardziej reprezentatywny $\mathrm{z}$ nich uznawany jest rękopis РГБ, собр. УНдольского (Ф. 310), № 1289, z przełomu XV/XVI w. (Творогов 1975, s. 12; Творогов 1987, s. 469; Анисимова 2009, s. 89-123, 131-171, 187-196, 223-257).

Treść źródła bizantyńskiego została w interesujących nas tu fragmentach Latopisu helleńskiego i rzymskiego drugiej redakcji przytoczona w całości, bez skrótów i bez jakichkolwiek odautorskich uzupełnień. Różnice między tekstem БАН, 33.8 .13 (fol. 287d-288d, 290a-290b, 290d) a odpisem РГБ, собр. Ундольского (Ф. 310), № 1289 (fol. 396-397', 399-399', 400) - stanowiącym podstawę edycji słowiańskiego przekładu Kontynuacji Jerzego Mnicha wersji B - ograniczają się tylko do poziomu stylistycznego i redakcyjnego, wyjąwszy zmiany, wynikające najprawdopodobniej z niezrozumienia przez kopistę sensu oryginału:

\begin{tabular}{|c|c|c|}
\hline $\begin{array}{c}\text { Latopis helleński i rzymski } \\
\text { drugiej redakcji } \\
\text { (БАН, 33.8.13) }\end{array}$ & $\begin{array}{l}\text { Staro-cerkiewno-słowiański } \\
\text { przekład Kontynuacji Jerzego } \\
\text { Mnicha } \\
\text { (РГБ, собр. Ундольского } \\
\text { [Ф. 310], № 1289) }\end{array}$ & Tekst oryginalny \\
\hline 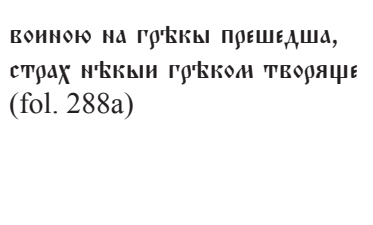 & 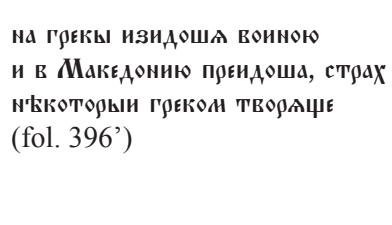 & 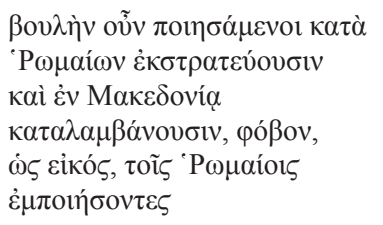 \\
\hline 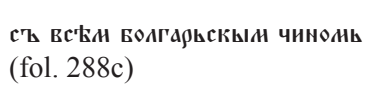 & 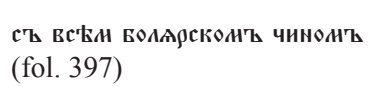 & $\pi \alpha ́ \sigma \eta\rceil \eta \tilde{~} \sigma v \gamma \kappa \lambda \eta ́ \tau \omega$ \\
\hline 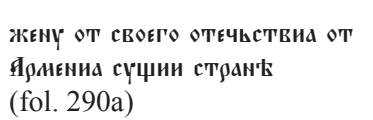 & 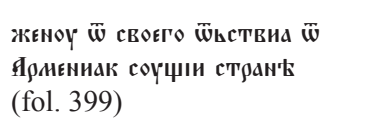 & 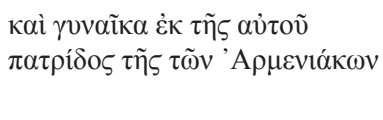 \\
\hline
\end{tabular}

Fragmenty Latopisu helleńskiego i rzymskiego drugiej redakcji, poświęcone Piotrowi i Marii, można uznać, de facto, za wariant tekstu Kontynuacji Jerzego Mnicha / kroniki Symeona Logotety, tzw. wersji B. Co więcej, jest to wariant niezwykle wierny oryginałowi greckiemu. Oprócz wymienionych wyżej passusów, w których natrafiamy na różnice treści Latopisu helleńskiego i rzymskiego względem słowiańskiego przekładu redakcji B Kontynuacji Jerzego Mnicha, porównując interesujący nas tu zabytek z greckim tekstem kroniki bizantyńskiej, wskazać można tylko na kilka rozbieżności/osobliwości terminologicznych, przejętych przez autorów Latopisu helleńskiego i rzymskiego bezpośrednio z tłumaczenia źródła na język scs. Oto najważniejsze z nich: 
1. Tytulatura władców bułgarskich - w opisie wydarzeń sprzed podpisania traktatu pokojowego w 927 r., w którym strona bizantyńska uznała prawo Piotra do posługiwania się tytułem cesarskim, osoby sprawujące rządy nad Bułgarami określane są terminem кнлзь (odpowiadającym gr. ó $\rho \chi \omega v)$; w narracji na temat wypadków późniejszych syn Symeona nazywany jest natomiast apelatywem ц्j, (tożsamym $\mathrm{z}$ gr. $\beta \alpha \sigma i \lambda \varepsilon \dot{\varsigma} \varsigma$ ).

2. Bizantyńczycy - konsekwentnie określani są, podobnie jak we wszystkich tekstach staroruskich, mianem Greków (гяłкы), a nie Rzymian ('P

3. Sąsiedzi Bułgarii - autor słowiańskiego przekładu Kontynuacji Jerzego Mnicha, a w ślad za nim twórcy Latopisu helleńskiego i rzymskiego nadmieniają o tym, iż państwu Piotra zagrażali w 927 r. Węgrzy (үгры), podczas gdy historiografowie bizantyńscy wspominają w tym miejscu o Turkach (Toũ

Tekst staroruski Latopisu helleńskiego i rzymskiego drugiej redakcji został wydany w 1999 r. przez O.W. Tworogowa (Летописеи Еллинский и Римский, vol. I, Текст, wyd. О.В. Творогов, Санкт-Петербург 1999). Całościowych przekładów na języki nowożytne brak.

Kontynuacja Jerzego Mnicha i odpowiadające jej fragmenty kroniki Symeona Logotety (wersja A) w oryginale greckim były publikowane kilkakrotnie. Wśród wydań zabytku wymienić można: Georgius Monachus, Vitae imperatorum recentiorum, wyd. I. Bekker, CSHB, Bonnae 1838, s. 761-924; Symeonis Magistri et Logothetae Chronicon, wyd. S. Wahlgren, CFHB (Series Berolinensis) 44/1, Berolini-Novi Eboraci 2006. Istnieje również edycja cerkiewnosłowiańskiego przekładu redakcji A Kontynuacji Jerzego Mnicha, wykonanego na Bałkanach w XIV w. (В.И. Срезневский, Симеона Метафраста и Логофета описание мира от бытия и летовниксобран от различных летописеи. Славянский перевод Хроники Симеона Логофета с дополнениями, Санкт-Петербург 1905, s. 1-144). Jak dotąd nie zostało natomiast przygotowane do druku całościowe wydanie krytyczne tekstu greckiego wariantu B interesującego nas tu źródła. Powinno się ono ukazać $\mathrm{w}$ ciągu najbliższych lat $\mathrm{w}$ ramach serii CFHB (Series Berolinensis), jako tom 44/2. Fragmenty różnicujące wersje A i B kroniki opublikowano tylko w formie lekcji do tekstu redakcji A Kontynuacji Jerzego Mnicha w tomie 110 serii Patrologia Graeca z 1863 roku. Tłumaczenie wariantu B na język staro-cerkiewno-słowiański, powstałe w Bułgarii $\mathrm{w}$ X-XI w., wydano natomiast już na początku XX stulecia: B.М. Истрин, Книгы временыя и образныя Георгия Мниха. Хроника Георгия Амартола в древнем славянорусском переводе. Текст, исследование и словарь, t. 1, Петроград 1920. W drugim tomie tej ostatniej publikacji znajduje się też tekst grecki Kontynuacji Jerzego Mnicha redakcji B wg rękopisu Vat. gr. 153 (t. 2, Петроград 1922, s. 1-65). 
Oryginalny, grecki tekst szóstej księgi Kontynuacji Teofanesa, zależny od redakcji B Kontynuacji Jerzego Mnicha i kroniki Symeona Logotety, został opublikowany: Theophanes Continuatus, wyd. B.G. Niebuhr, red. I. Bekker, Bonnae 1838. Fragmenty tego źródła, dotyczące Piotra i Marii Lekapeny przełożyła na język polski Alina Brzóstkowska (Testimonia najdawniejszych dziejów Słowian. Seria grecka, t. 5, Pisarze z X wieku, tłum., oprac. A. Brzóstkowska, Warszawa 2009, s. 54-59).

\section{TEKST ŹRÓDŁA W ORYGINALE STARORUSKIM}

Tekst wg odpisu БАН, 33.8.13, datowanego na ostatnią tercję XV wieku. Przedrukowano za: Летописец Еллинский и Римский, vol. I, Текст, red. O.В. Творогов, Санкт-Петербург 1999, s. 497-498, 500, 501.

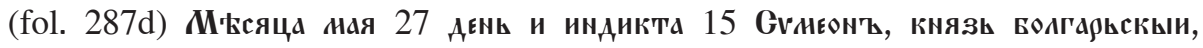

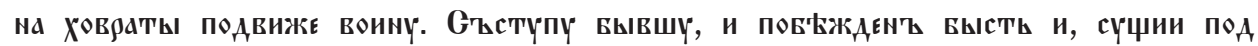

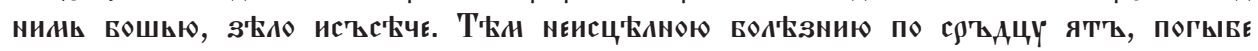

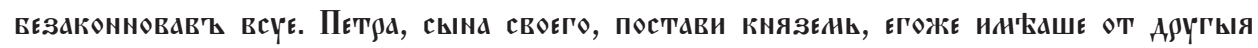

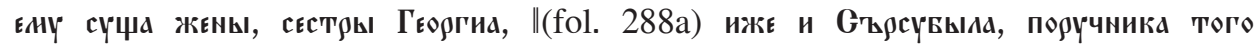

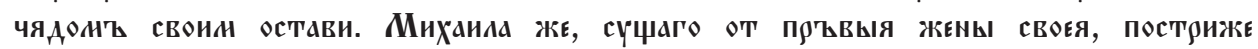

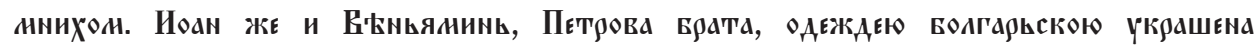

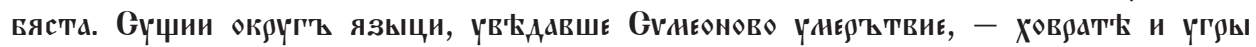

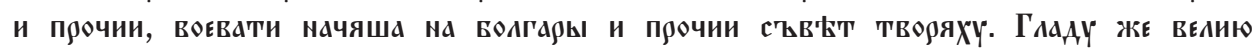

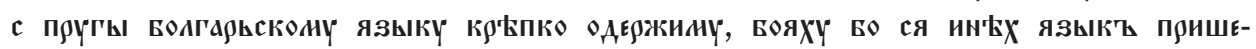

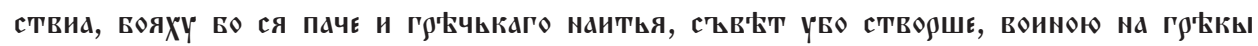

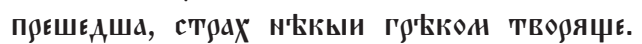

По сих Же Пакы үв'Адаше, яко Хоџет на ня Царь вонною изити Ронанъ,

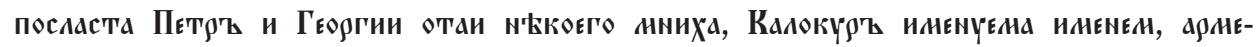

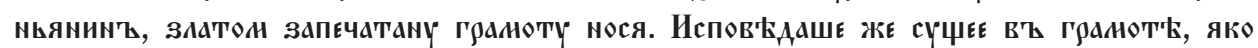

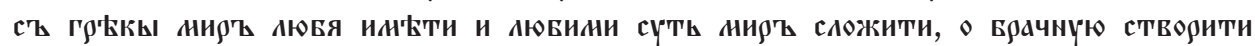

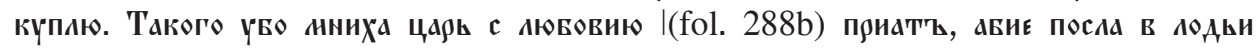

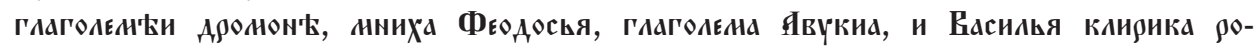

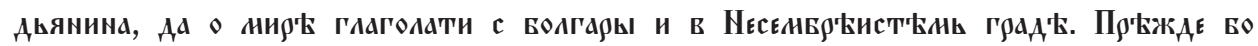

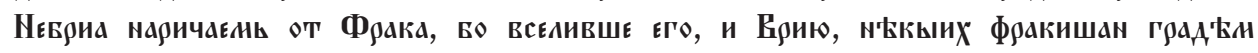

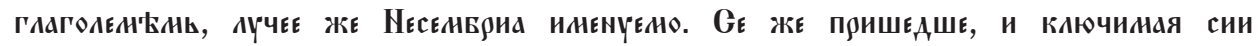

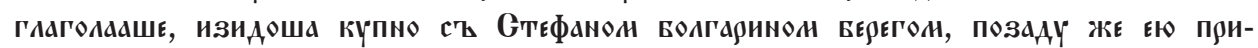

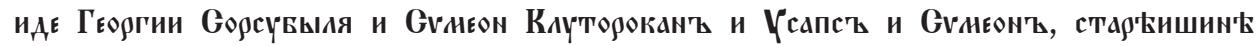

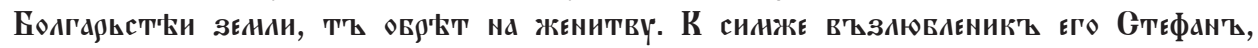

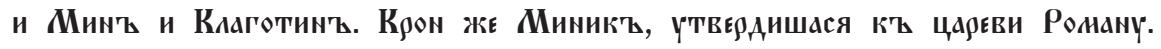




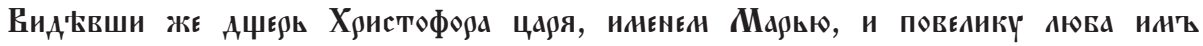

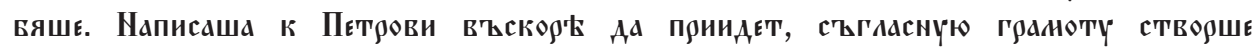

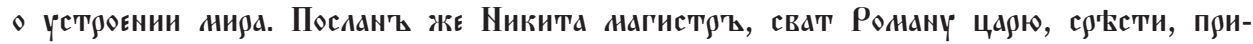

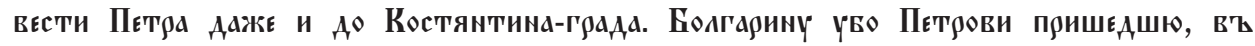

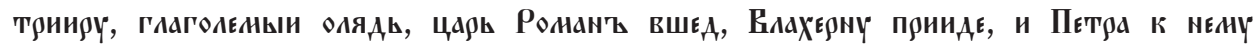

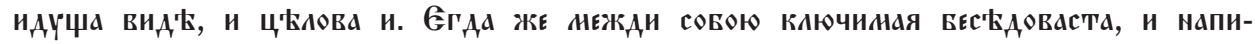

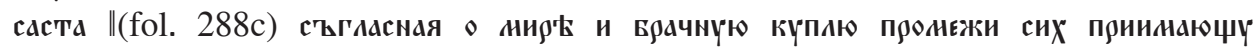

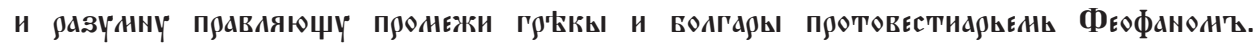

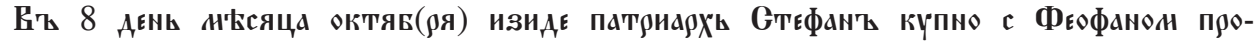

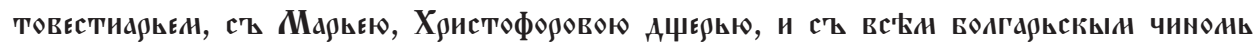

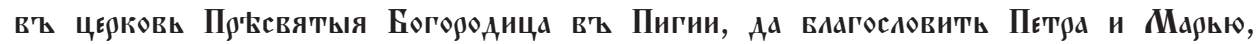

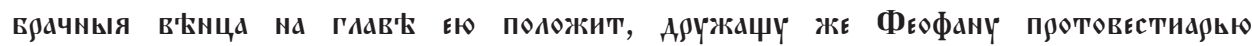
и Георгию Gорсүьыли.

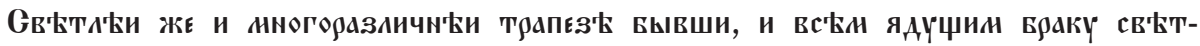

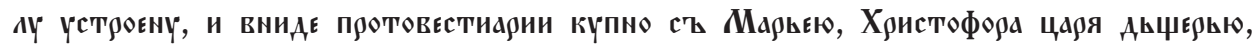

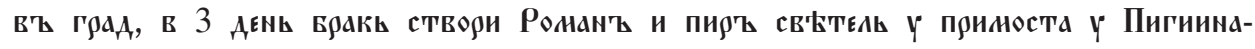

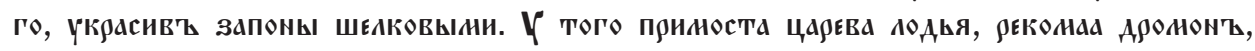

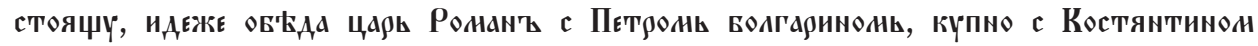

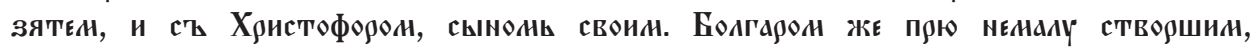

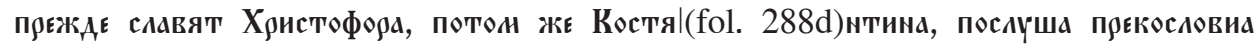

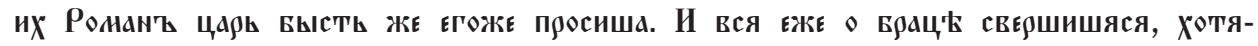

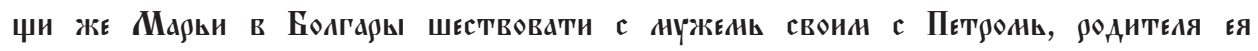

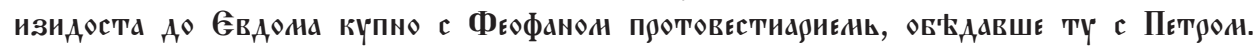
ХОТЯЧИН ЖЕ ИН ИТИ ПЮОЧЬ, ОББЕАШИН АЧЕ९Ь И ННОГЫ САЕЗЬ ПЮОАЬЯВШИН, ЯКО

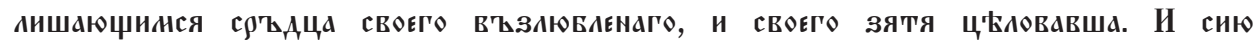

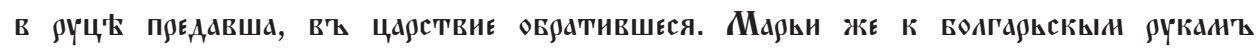

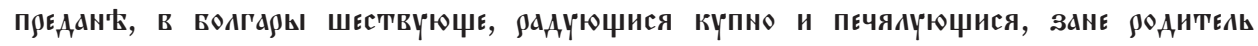

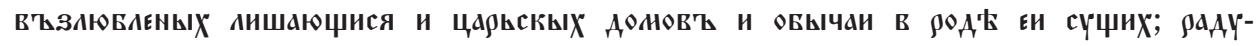

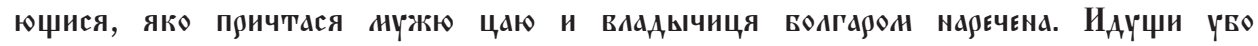
и БоГатство носячи всякое и ПЛИСТ९ОИ БЕЗЬ ЧИСА.

$$
[\ldots]
$$

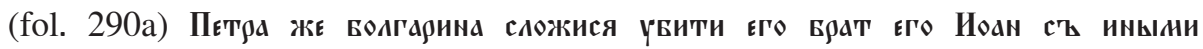

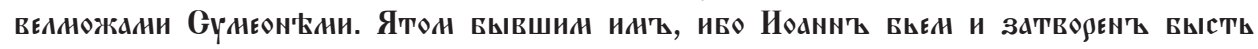

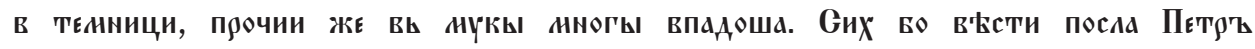

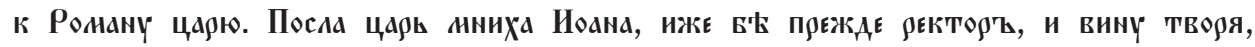

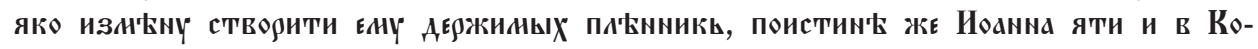

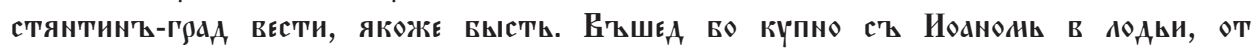

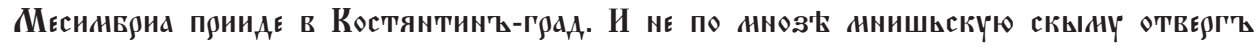

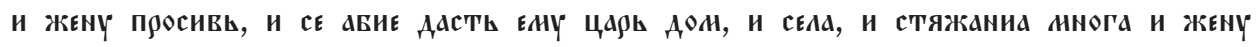

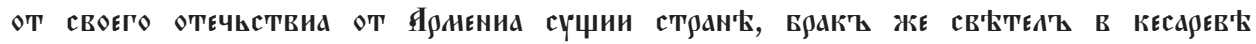




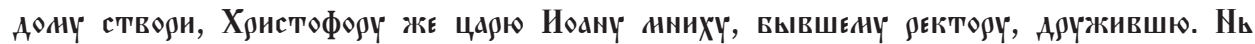

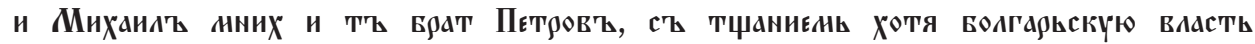

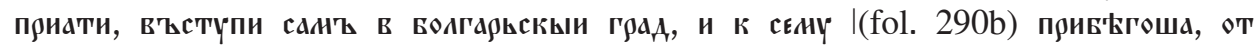

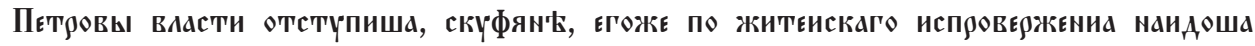

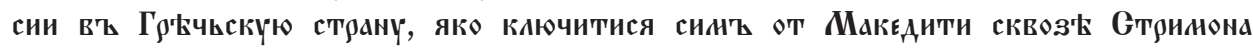
на Gadaү и на Никополии внити, тү сүџая вся пл'анити. Никополии же рекодыи

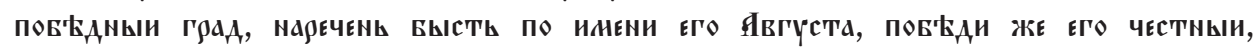

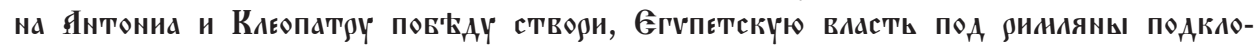
ни.

$[\ldots]$

(fol. 290d) И Прежаєеєчеnнaго Царя Ронана внүка, жена же Петра болГарина,

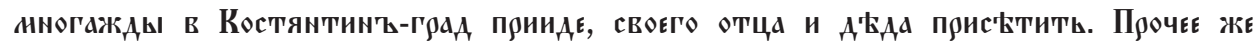

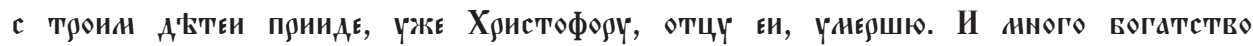

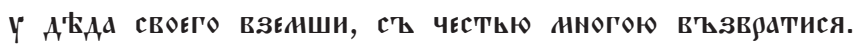

\section{PRZEKŁAD POLSKI}

W dniu 27 maja piętnastej indykcji [927 r.] Symeon, książę bułgarski wyprawił się zbrojnie na Chorwatów. Kiedy doszło do bitwy, został pokonany i wygubił wszystkich swoich podkomendnych. Od tego nieuleczalną chorobą w serce ugodzony, zginął - dopuszczając się bezprawia na próżno ${ }^{2}$. Ustanowił księciem swojego syna Piotra ${ }^{3}$, którego miał ze swoją drugą żoną, siostrą Jerzego Sursuwuła ${ }^{4}$. Jego też wyznaczył swoim dzieciom na opiekuna. Michała, zrodzonego z pierwszej żony, postrzygł na mnicha. Jan i Beniamin, bracia Piotra ${ }^{5}$, byli zaś przyozdobieni

${ }^{2}$ Symeon I Wielki - władca bułgarski (893-927). Zmarł w 927 roku. Informacja o tym, iż przyczyną zgonu Symeona był atak serca, wywołany traumatycznym przeżyciem (klęską wojsk bułgarskich w starciu z Chorwatami), pojawia się w redakcji B Kontynuacji Jerzego Mnicha i kroniki Symeona Logotety, a także - w bazującej na ich przekazie - Kontynuacji Teofanesa. Można polemizować, czy nagła śmierć tego władcy rzeczywiście miała bezpośredni związek z porażką jego wojsk, niemniej jednak nie ulega wątpliwości inna kwestia - w pierwszych miesiącach rządów Piotra stosunki bułgarsko-chorwackie były bardzo napięte.

${ }^{3}$ Piotr I - cesarz/car bułgarski (927-969). Syn Symeona I Wielkiego i jego drugiej żony, nieznanej nam z imienia siostry Jerzego Sursuwuła. W 927 r. poślubił Marię, wnuczkę Romana I Lekapena. Małżeństwo to miało gwarantować trwałość podpisanego wówczas w Konstantynopolu pokoju bułgarsko-bizantyńskiego.

${ }^{4}$ Jerzy Sursuwuł - wuj Piotra ze strony matki. Symeon I Wielki przed śmiercią wyznaczył go na opiekuna swoich dzieci i regenta. W źródłach bizantyńskich pojawia się tylko w opisie wydarzeń z 927 roku.

${ }^{5}$ Piotr miał trzech braci: przyrodniego Michała (ok. 900-ok. 930), który jeszcze za życia Symeona został mnichem, a także Jana (po 903-po 929) i Beniamina. Nie jest jasne, czy dwaj ostatni byli rodzonymi braćmi bułgarskiego cara, czy też jego przyrodnim rodzeństwem. 
strojem bułgarskim. Znajdujący się wokół obcoplemieńcy (Chorwaci, Węgrzy i inni) ${ }^{6}$, dowiedziawszy się o śmierci Symeona, rozpoczęli wojnę przeciwko Bułgarom i zawiązali sprzysiężenie. Ponieważ naród bułgarski był przemożnie owładnięty wielkim głodem od szarańczy, bał się najazdu innych ludów, a najbardziej lękał się ataku greckiego. Podjąwszy więc decyzję, [Bułgarzy] zbrojnie wyprawili się na Greków, stanowiąc dla nich pewne zagrożenie ${ }^{7}$.

Dowiedziawszy się zaś później, że cesarz Roman ${ }^{8}$ chce wyruszyć na nich z wojskiem, Piotr i Jerzy wysłali potajemnie pewnego mnicha, zwącego się imieniem Kalokir ${ }^{9}$, Armeńczyka, niosącego zamknięty złotą pieczęcią dokument. Deklarowali zaś w tym piśmie, że pragnęliby mieć pokój z Grekami i skłonni są zawrzeć pokój oraz układ małżeński. Wspomnianego mnicha cesarz przyjął z miłością. Zaraz też wysłał w łodzi nazywanej dromonem mnicha Teodozjusza, zwanego Abukesem $^{10}$, oraz duchownego Bazylego Rodyjczyka ${ }^{11}$, aby porozmawiali z Bułgarami o pokoju w mieście Mesembria. Była ona wcześniej nazywana Nebrią lub Brią od imienia Traka, którego tu osiedlono, i określana miastem ,jakichś Traków”. Lepiej więc zwać ją Mesembrią ${ }^{2}$. [Posłowie] przybywszy, omówili kluczowe kwestie i wyruszyli razem ze Stefanem Bułgarem ${ }^{13}$ brzegiem. Za nimi udali się zaś Jerzy

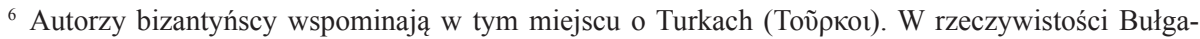
rii zagrażali wtedy jednak Węgrzy, wzmiankowani przez źródła słowiańskie.

${ }^{7}$ Autorzy Latopisu helleńskiego i rzymskiego drugiej redakcji pominęli tu pewien dość istotny szczegół, odnotowany przez źródła bizantyńskie oraz staro-cerkiewno-słowiański przekład Kontynuacji Jerzego Mnicha, tj. wzmiankę o zajęciu przez wojska bułgarskie w 927 r. Macedonii.

8 Roman I Lekapen - cesarz bizantyński (920-944). Był dowódcą wojskowym, który poprzez małżeństwo swojej córki Heleny z prawowitym bazyleusem, Konstantynem VII Porfirogenetą, zdołał przejąć pełnię władzy cesarskiej w Konstantynopolu i utrzymać ją przez ponad dwadzieścia lat, do roku 944, pod którego koniec został zdetronizowany przez własnych synów, Stefana i Konstantyna.

9 Kalokir - mnich. Wywodził się z Armenii. W 927 r. został wysłany przez Piotra i Jerzego Sursuwuła z poselstwem do Konstantynopola. O jego dalszych losach nic nam nie wiadomo.

10 Teodozjusz Abukes - mnich. W 927 r. posłował w imieniu cesarza Romana I Lekapena do bułgarskiego władcy Piotra. Jest to jedyny epizod z jego życia poświadczony źródłowo.

11 Wł. Konstantyn Rodyjczyk (ok. 870/880 - po 931) - syn Jana i Eudokii, osiadłych w Lindos na wyspie Rodos. Poeta i dyplomata. W 908 r. trafił na dwór cesarza Leona VI Mądrego, a po jego śmierci przebywał w otoczeniu Konstantyna VII Porfirogenety. W 927 r. wraz z Teodozjuszem Abukesem został wysłany przez Romana I z poselstwem do władcy Bułgarii. Anonimowy autor Kontynuacji Jerzego Mnicha, a w ślad za nim twórcy Latopisu helleńskiego $i$ rzymskiego drugiej redakcji nazywają go Bazylim, najprawdopodobniej wskutek zbieżności brzmieniowej tego imienia z przyna-

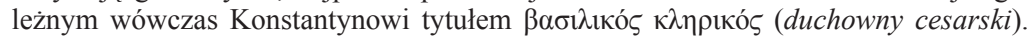

${ }_{12}$ Mesembria - ob. Nesebyr. Miasto portowe na zachodnim brzegu Morza Czarnego. Rzeczywiście zostało założone przez ludność tracką i w najwcześniejszym okresie istnienia znane było pod nazwą Menebria. W VI w. p.n.e. przekształcone w kolonię grecką, zasiedloną przez osadników z Megary. W IX-X w. Mesembria kilkakrotnie przechodziła spod rządów bizantyńskich pod panowanie bułgarskie i vice versa. W 927 r. władali nią Bułgarzy.

13 Stefan Bułgar - był bliskim krewnym Piotra, niektórzy badacze przyjmują, że jego bratem stryjecznym, a także jedną z najbardziej wpływowych politycznie osób w ówczesnej Bułgarii. W 927 r. zapoczątkował rozmowy pokojowe z członkami poselstwa bizantyńskiego, przybyłymi do Mesembrii, a następnie wchodził w skład delegacji, wysłanej z Presławia nad Bosfor. 
Sursuwuł, kalutarkan i sampsis Symeon oraz Symeon, który stał się dostojnikiem ziemi bułgarskiej przez małżeństwo, a także jego ukochany Stefan, menikos, magotinos, kronos i menikos zjawili się u cesarza Romana ${ }^{14}$.

Gdy ujrzeli córkę cesarza Krzysztofa ${ }^{15}$ o imieniu Maria ${ }^{16}$, która bardzo im się spodobała, napisali do Piotra, aby przybył czym prędzej - uprzednio przygotowali akt porozumienia o zawarciu pokoju. Wysłany został magister Niketas, powinowaty cesarza Romana ${ }^{17}$, aby spotkał Piotra [po drodze] i przyprowadził go aż do Konstantynopola. Kiedy zaś przybył Piotr Bułgar, cesarz Roman, wsiadłszy na pokład triery, tzn. okrętu, przypłynął do Blachern ${ }^{18}$, ujrzał Piotra idącego ku niemu i ucałował go. Kiedy omówili między sobą kluczowe kwestie, spisali akt porozumienia pokojowego i układu małżeńskiego, zawieranego między obiema stronami - pośredniczył zaś umiejętnie między Grekami i Bułgarami protowestiariusz Teo-

14 Trudno odtworzyć skład bułgarskiego poselstwa. Najprawdopodobniej znajdowali się w nim, oprócz Jerzego Sursuwuła i Stefana Bułgara, następujący dostojnicy: Symeon, sprawujący urzędy

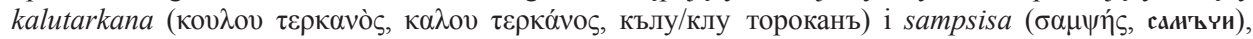
będący - być może - mężem siostry Symeona I Wielkiego, Anny; inny Symeon, spowinowacony z bułgarską rodziną panującą przez żonę - być może był on szwagrem Piotra, tj. mężem jego siostry;

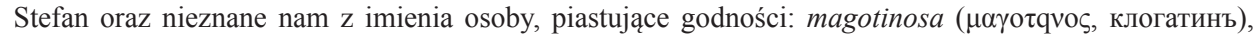

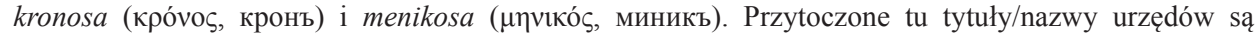
pochodzenia protobułgarskiego (Славова 2010, s. 81-83, 105-129).

15 Krzysztof Lekapen (ok. 890-931) - najstarszy syn cesarza Romana I Lekapena i jego żony Teodory. Mąż Zofii, córki magistra Niketasa. Ojciec bułgarskiej carycy, Marii Lekapeny. Podniesiony w 921 r. przez swojego ojca do rangi współcesarza i trzeciego koregenta cesarstwa. W 927 r., rzekomo na prośbę członków bułgarskiego poselstwa, awansowany na drugie miejsce w hierarchii panujących, kosztem Konstantyna VII Porfirogenety.

${ }^{16}$ Maria Lekapena (ok. 912-963) - bułgarska caryca (927-963). Pierworodne dziecko Krzysztofa Lekapena i Zofii, córki magistra Niketasa. W 927 r. poślubiła bułgarskiego władcę Piotra. Jej małżeństwo, uroczyście zawarte w Konstantynopolu, miało za zadanie umocnić świeżo podpisany pokój bizantyńsko-bułgarski. Zdaniem Liutpranda z Cremony, by podkreślić znaczenie tego mariażu dla relacji między obu państwami, Maria wychodząc za mąż, przybrała nowe imię - Irena (Pokój). Matka dwóch późniejszych carów bułgarskich: Borysa II (969-971) i Romana (?977-991/997), a być może również syna o imieniu Plenimir i kilku córek.

${ }_{17}$ Niketas (ok. 870-po 946) - magister. Wywodził się ze słowiańskiej rodziny z Peloponezu. Był ojcem Zofii, małżonki Krzysztofa Lekapena. W 928 r. za udział w spisku przeciwko cesarzowi Romanowi I (miał zachęcać swojego zięcia do sięgnięcia po najwyższą władzę) został wydalony z Konstantynopola i zmuszony do przywdziania mniszych szat.

${ }_{18}$ Blacherny - rejon Konstantynopola, usytuowany w północno-zachodniej części miasta, na południowym brzegu zatoki Złoty Róg. Obszar ten znajdował się poza obrębem właściwego muru Teodozjusza II. W linię fortyfikacyjną włączony został za panowania cesarza Herakliusza. Wzmiankowany w wielu źródłach kościół Bogurodzicy w Blachernach był de facto kompleksem trzech budowli (Wielki Kościół, kaplica św. Relikwiarza i Święte Łaźnie), ufundowanym w połowie V w. przez cesarzową Pulcherię. Najcenniejszą relikwią przechowywaną w analizowanej świątyni była szata (maforion) Matki Bożej, sprowadzona do Konstantynopola z Ziemi Świętej w drugiej połowie $\mathrm{V}$ wieku. Znajdowała się tam również cudowna ikona Bogurodzicy. Wierzono, że blacherneńskie relikwie oraz wizerunek Marii kilkukrotnie ocaliły bizantyńską stolicę przed najazdem nieprzyjaciół (np. w 626 r. - przed Persami i Awarami, w 860 r. - przed Rusami). 
fanes ${ }^{19}$. W dniu 8 października wyruszył patriarcha $\operatorname{Stefan}^{20}$ wraz z protowestiariuszem Teofanesem, Marią, córką Krzysztofa, oraz wszystkimi bułgarskimi dostojnikami $^{21}$ do kościoła Przenajświętszej Bogurodzicy w Pege ${ }^{22}$, aby pobłogosławić Piotra i Marię i włożyć im na głowy ślubne wieńce, w obecności protowestiariusza Teofanesa i Jerzego Sursuwuła.

Kiedy odbyło się wspaniałe i różnorodne przyjęcie ze wszystkimi potrawami przepisanymi świetnej uczcie weselnej, wrócił protowestiariusz wraz z Marią, córką cesarza Krzysztofa, do miasta. Na trzeci dzień Roman urządził wesele i ucztę wspaniałą na nadbrzeżu w Pege, przyozdobiwszy je jedwabnymi zasłonami. Przy tym nadbrzeżu była zacumowana łódź cesarska, zwana dromonem, na której biesiadował cesarz Roman z Piotrem Bułgarem, wraz ze [swoim] zięciem Konstantynem $^{23}$ i Krzysztofem, synem swoim. Gdy Bułgarzy niemały sprzeciw podnieśli, aby najpierw sławić Krzysztofa, a potem dopiero Konstantyna, cesarz Roman wysłuchał ich protestów i stało się to, o co prosili. Kiedy zaś dopełniono wszystkiego w związku ze ślubem, a Maria miała wyruszyć do Bułgarii ze swoim mężem

19 Teofanes - protowestiariusz. Po 925 r. jest też wspominany w źródłach jako ó $\pi \alpha \tau \rho i ́ k 1 o \varsigma$

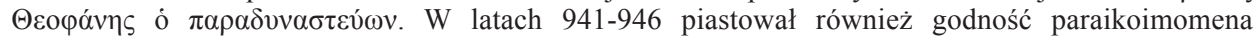

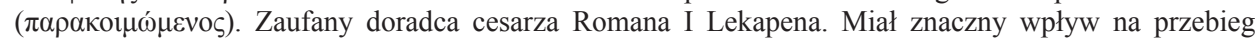
negocjacji pokojowych w 927 roku.

${ }^{20}$ Stefan II z Amasei (zm. 928) - patriarcha Konstantynopola w latach 925-928.

${ }^{21}$ Przekaz Latopisu helleńskiego i rzymskiego drugiej redakcji uległ tu pewnemu skażeniu, wynikającemu zapewne z pomyłki kopisty. W staro-cerkiewno-słowiańskim przekładzie Kontynuacji Jerzego Mnicha w tym miejscu narracji odnajdujemy bowiem frazę съ всьм болмрскомъ чиномъ (РГБ,

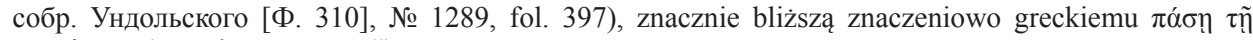

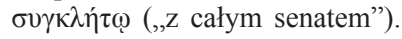

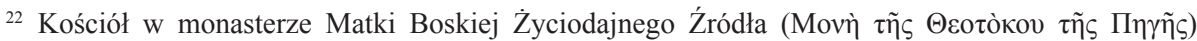
- usytuowany na przedmieściach Konstantynopola, poza obrębem muru Teodozjusza II, na południowy zachód od miasta. Swą nazwę zawdzięczał znajdującemu się w jego pobliżu źródłu, z którego wypływała woda o właściwościach leczniczych. Najstarszy kościół wzniesiono tu w VI w., w ostatnich latach panowania Justyniana I Wielkiego. Był on kilkakrotnie odrestaurowywany i przebudowywany: przez cesarzową Irenę (po trzęsieniu ziemi w 790 r.) i Bazylego I (po kolejnym tego rodzaju kataklizmie w 869 r.). We wrześniu 923 r. przybytek został zniszczony przez wojska bułgarskie. Jego odbudowy podjął się Roman I. Obrzęd zawarcia małżeństwa między wnuczką Lekapena a synem Symeona, odbywający się w tej świątyni, mógł zatem mieć czytelne znaczenie propagandowe: sugerować, że to Roman jest osobą, której udało się zniwelować zagrożenie ze strony Bułgarów, a poniekąd nawet - naprawić szkody, wyrządzone przez nich na terenie cesarstwa w przeszłości.

${ }^{23}$ Konstantyn VII Porfirogeneta - cesarz bizantyński (913-959), syn Leona VI Mądrego. Ustanowiony współwładcą przez swego ojca w 908 r., bazyleusem stał się po śmierci stryja Aleksandra w 913 roku. Ponieważ miał wówczas zaledwie siedem lat, początkowo rządy regencyjne w jego imieniu sprawował patriarcha konstantynopolitański Mikołaj Mistyk, a następnie cesarzowa Zoe Karbonopsina, matka małoletniego cesarza. W 919 r. stanowisko regenta przejął Roman Lekapen, który ożeniwszy Konstantyna VII ze swą córką Heleną, już w roku następnym zagarnął dla siebie władzę cesarską, odsuwając „urodzonego w purpurze" syna Leona VI od faktycznych rządów na wiele lat. W $927 \mathrm{r}$. zdegradował Konstantyna VII na trzecie miejsce w hierarchii panujących, dając pierwszeństwo przed nim Krzysztofowi Lekapenowi, swojemu najstarszemu synowi. Samodzielnym monarchą stał się Porfirogeneta dopiero w 945 r., po zdetronizowaniu teścia i pozbawieniu wpływów jego synów. 
Piotrem, rodzice jej ${ }^{24}$ udali się do Hebdomonu ${ }^{25}$ wraz z protowestiariuszem Teofanesem i tam spożyli obiad z [nią i z] Piotrem. Gdy [nowożeńcy] mieli ruszać dalej, [rodzice] objęli córkę, wylewając bezmiar łez, jakby tracili serce swe ukochane, i ucałowali swojego zięcia. I przekazawszy ją w jego ręce, powrócili do cesarstwa. Maria zaś, oddana w bułgarskie ręce, udawała się do Bułgarii, radując się, a jednocześnie smucąc, gdyż została pozbawiona ukochanych rodziców, cesarskich siedzib i obyczajów, przestrzeganych w jej rodzie. Cieszyła się zaś z tego, że związała się z mężczyzną-cesarzem i została nazwana władczynią Bułgarów ${ }^{26}$. Odjeżdżała, wioząc wszelakie bogactwa i niezliczone sprzęty.

\section{$[\ldots]$}

Piotra Bułgara sprzysięgli się zabić jego brat Jan ${ }^{27}$ oraz inni dostojnicy Symeona. Kiedy zostali schwytani, Jan został ubiczowany i wtrącony do więzienia, pozostali zaś - wydani na ciężkie męki. Piotr powiadomił o tym cesarza Romana. Cesarz wysłał mnicha Jana, który wcześniej był rektorem²8, tworząc przyczynę, żeby dokonał on wymiany trzymanych w niewoli jeńców ${ }^{29}$. W rzeczywistości miał

${ }^{24}$ Krzysztof Lekapen (vide przyp. 14) i jego małżonka Zofia (ok. 890-po 959), córka magistra Niketasa. Do godności augusty została wyniesiona najprawdopodobniej w lutym 922 r., po śmierci Teodory, żony cesarza Romana I. Ostatnia wzmianka źródłowa na temat tej władczyni pochodzi z 959 r. - była ona wówczas mniszką w monasterze Kanikleiu.

${ }^{25}$ Hebdomon - przedmieścia Konstantynopola, usytuowane na południowy zachód od miasta, na północnym wybrzeżu morza Marmara.

${ }^{26}$ Anonimowy kontynuator kroniki Jerzego Mnicha, Symeon Logoteta, autor Kontynuacji Teofanesa, a w ślad za nimi twórcy Latopisu helleńskiego i rzymskiego drugiej redakcji, odnotowują w tej partii narracji niezwykle istotny szczegół: Maria Lekapena zaraz po ślubie z Piotrem miała zostać

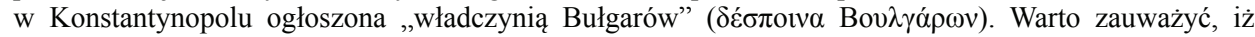
termin $\delta \varepsilon ́ \sigma \pi$ olv $\alpha$ był apelatywem przysługującym konstantynopolitańskim cesarzowym, używanym przez nie wymiennie z tytułami $\alpha$ jov́ $\sigma \tau \alpha$ i $\beta \alpha \sigma i ́ \lambda \iota \sigma \sigma \alpha$. Analizowany passus dowodzi, zdaniem wielu badaczy, iż w 927 r. strona bizantyńska oficjalnie uznała prawo bułgarskiego władcy do posługiwania się tytułem cesarskim.

27 Jan (po 903-po 929) - rodzony lub przyrodni brat Piotra. Spróbował w 928 r., na drodze spisku pałacowego, przechwycić władzę w Presławiu. Trudno jednoznacznie ustalić, jakie były przyczyny jego wystąpienia. Być może był starszym synem Symeona, desygnowanym początkowo na jego następcę. Mógł też zostać wyznaczony na sukcesora Piotra. W literaturze przedmiotu pojawia się również pogląd, iż Jan wraz z bratem Benjaminem stał na czele stronnictwa sprzeciwiającego się prowadzonej przez Piotra i Jerzego Sursuwuła polityce zbliżenia z cesarstwem oraz nasilaniu się wpływów bizantyńskich w Bułgarii. Materiał źródłowy nie pozwala jednak na ostateczne potwierdzenie tej tezy (Leszka 2016, s. 5-11).

${ }^{28}$ Jan - mnich, były rektor. Najstarsza wzmianka źródłowa na jego temat pochodzi z 921 r. dowodził wówczas (wraz z Leonem i Potosem Argyrosami) wojskami cesarskimi, skierowanymi przez Romana I Lekapena do walki z oddziałami Symeona I Wielkiego, plądrującymi okolice Konstantynopola. Starcie z Bułgarami okazało się jednak klęską, a Jan uciekł z pola walki. W 929 r. został wysłany z poselstwem do Presławia, którego oficjalnym powodem miało być dokonanie wymiany jeńców, prawdziwą zaś przyczyną - wywiezienie do bizantyńskiej stolicy brata Piotra, Jana.

${ }^{29}$ Dokonanie wymiany jeńców wojennych było zapewne jednym z postanowień traktatu z 927 roku. Zostało ono zrealizowane najprawdopodobniej w 929 roku. Konstantyn VII Porfirogeneta oraz 
on natomiast schwytać Jana i przywieźć go do Konstantynopola. Tak się też stało. Wsiadłszy bowiem razem z Janem na statek, [brat Piotra] przybył z Mesembrii do Konstantynopola. I nie minęło wiele czasu, jak odrzucił mnisze śluby i poprosił o żonę, a cesarz wnet podarował mu dom, i wsie, i majętności wiele, i żonę pochodzącą z ojczystego kraju [Romana], z Armenii ${ }^{30}$. Zorganizował też uroczysty ślub w domu współcesarza, na którym świadkowali cesarz Krzysztof i mnich Jan, były rektor. Lecz i mnich Michał ${ }^{31}$, także będący bratem Piotra, usilnie pragnąc przejąć władzę w Bułgarii, zajął sam [pewien] gród bułgarski i przybiegli do niego, zbuntowawszy się przeciwko władzy Piotra, Scytowie ${ }^{32}$. Gdy został on [Michał] pozbawiony życia, [jego stronnicy] znaleźli się w kraju greckim, tj. udało im się przejść od Maketydy ${ }^{33}$ przez Strymon $^{34}$ do Hellady ${ }^{35}$ i do Nikopola ${ }^{36}$, a także zawładnąć wszystkim, co tam było. Nikopol, tzw. miasto zwycięstwa, zostało nazwane na pamiątkę zwycięstwa, które czcigodny August odniósł nad Antoniuszem i Kleopatrą. Podporządkował Egipt Rzymianom ${ }^{37}$.

autor Mowy na pokój z Bułgarami zaświadczają, że konsekwencją zawarcia pokoju była wymiana jeńców, dzięki której wielu żołnierzy z armii bizantyńskiej, przebywających w niewoli bułgarskiej, powróciło do swojej ojczyzny.

${ }^{30} \mathrm{~W}$ źródłach bizantyńskich, staro-cerkiewno-słowiańskim przekładzie Kontynuacji Jerzego Mnicha, a nawet w innych odpisach Latopisu helleńskiego $i$ rzymskiego drugiej redakcji, jest w tym miejscu wspomniany tem Armeniakon. Roman I rzeczywiście wywodził się z rodziny armeńskiej, osiedlonej w Lekape w okolicach Metyleny i Samosaty (tem Lykandos).

31 Michał (ok. 900-ok. 930) - przyrodni brat Piotra, pierworodny syn Symeona I Wielkiego. Do jego wystąpienia doszło najprawdopodobniej w 930 roku.

32 Pod tym etnonimem kryją się najprawdopodobniej Bułgarzy.

33 Maketyda - termin niejasny, pojawiający się w wersji B Kontynuacji Jerzego Mnicha oraz

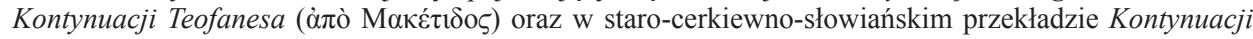
Jerzego Mnicha (ळ̄ Макетида). We wszystkich najstarszych odpisach Latopisu helleńskiego $i$ rzymskiego drugiej redakcji odnajdujemy lekcję: от Македити. Część badaczy, opierając się na przekazie kroniki Jana Skylitzesa, używającego w opisie interesujących nas tu wydarzeń określenia Macedonia, skłonna jest zakładać, iż obszarem, na którym doszło do wystąpienia Michała, była południowo-zachodnia część ówczesnego państwa bułgarskiego, tj. tereny macedońskie. Kwestia ta jest jednak o wiele bardziej złożona, a tym samym - trudno jednoznacznie określić, gdzie znajdował się ośrodek rebelii (Leszka 2017). Wydawca tekstu staroruskiego Latopisu helleńskiego i rzymskiego drugiej redakcji, O.W. Tworogow uznaje Maketydę za „twierdzę w Bułgarii”, a w indeksie wprowadza wyraźne rozróżnienie między analizowanym toponimem a Macedonią. Podobnie czyni V.M. Istrin w swej edycji słowiańskiego przekładu Kontynuacji Jerzego Mnicha oraz autor tłumaczenia Kontynuacji Teofanesa na współczesny język rosyjski, Ja.N. Ljubarski.

34 Strymon - ob. Struma, rzeka, mająca swoje źródła w górskim masywie Witoszy w okolicach Sofii, uchodząca do Morza Trackiego (północna część Morza Egejskiego).

35 Hellada - najprawdopodobniej autor źródła ma tu na myśli Epir, na którego obszarze osiedlili się zwolennicy Michała, przedostawszy się na terytorium bizantyńskie.

${ }^{36}$ Nikopol - miasto w Epirze, położone nad Zatoką Ambrakijską (Morze Jońskie). Rzeczywiście zostało założone przez Oktawiana Augusta w 31 r. p.n.e. po zwycięstwie nad Markiem Antoniuszem. W latach 30. X w. znajdowało się pod panowaniem bizantyńskim. Istniał wówczas również tem Nikopol ze stolicą w Naupaktos.

37 Autor wersji B Kontynuacji Jerzego Mnicha, a w ślad za nim twórcy Latopisu helleńskiego i rzymskiego drugiej redakcji odwołują się tu do wydarzeń z 31 r. p.n.e., tj. zwycięstwa, odniesione- 


\section{$[\ldots]$}

Wnuczka wspomnianego wyżej cesarza Romana, żona Piotra Bułgara, wielokrotnie przybywała do Konstantynopola, aby odwiedzić swojego ojca i dziadka. Po raz ostatni zaś przyjechała z trojgiem dzieci ${ }^{38}$, kiedy jej ojciec Krzysztof był już umarły ${ }^{39}$. Otrzymawszy od swojego dziadka wiele bogactw, powróciła [do Bułgarii] z niezwykłymi honorami.

\section{LITERATURA}

Leszka M.J. 2016, Spisek Jana przeciw carowi Piotrowi (928) - raz jeszcze, Balcanica Posnaniensia. Acta et studia, 23, s. 5-13.

Leszka M.J. 2017, Bunt Michała przeciw carowi Piotrowi (?930), „Slavia Antiqua”, 58 [w druku].

Markopoulos A. 1983, Sur les deux versions de la Chronographie de Symeon Logothete, Byzantinische Zeitschrift, 76.2, s. 279-284.

Swoboda W. 1965, Kontynuacja Georgiosa, w: W. Kowalenko, G. Labuda, T. Lehr-Spławiński, red., Slownik starożytności słowiańskich. Encyklopedyczny zarys kultury Stowian od czasów najdawniejszych do schytku XII w., t. 2.2, Wrocław, Zakład Narodowy im. Ossolińskich, s. 468.

Swoboda W. 1975, Symeon Logotheta, w: W. Kowalenko, G. Labuda, T. Lehr-Spławiński, red., Stownik starożytności stowiańskich. Encyklopedyczny zarys kultury Słowian od czasów najdawniejszych do schytku XII w., t. 5, Wrocław, Zakład Narodowy im. Ossolińskich, s. 506-507.

Treadgold W. 1979, The Chronological Accuracy of the Chronicle of Symeon the Logothete for the Years 813-845, Dumbarton Oaks Papers, 33, s. 157-198.

Wasilewski T. 1971, Macedońska historiografia dynastyczna X w. jako źródło do dziejów Bizancjum w latach 813-867, Studia Źródłoznawcze. Commentationes, 16, s. 59-83.

Анисимова Т.В. 2009, Хроника Георгия Амартола в древнерусских списках XIV-XVII вв., Москва, Издательство „Индрик”.

Бобров А.Г. 2004, К вопросу о времени и месте создания Летописиа Еллинского и Римского второй редакиии, Труды Отдела древнерусской литературы, 55, s. 82-90.

Вилкул Т. 2015, Літопис і хронограф. Студії з домонгольського київського літописання, Київ,

Горина Л.В. 2005, Болгарский хронограф и его судьба на Руси, София, Тангра.

go przez flotę Oktawiana Augusta nad okrętami Kleopatry VII - ostatniej królowej Egiptu z dynastii Ptolemeuszy, sprzymierzonej z Markiem Antoniuszem. Do bitwy morskiej doszło pod Akcjum (w okolicach późniejszego Nikopola). W rok później Egipt przeszedł pod panowanie rzymskie.

${ }^{38}$ Autorzy Latopisu helleńskiego i rzymskiego drugiej redakcji, w ślad za twórcą najstarszego tłumaczenia Kontynuacji Jerzego Mnicha na język staro-cerkiewno-słowiański, użyli tu określenia, które nie precyzuje płci potomstwa bułgarskiej carycy. Analogiczny termin pojawia się też w tekstach greckich $(\mu \varepsilon \tau \dot{\alpha} \pi \alpha i \delta \omega v \tau \rho t \tilde{v})$. XIV-wieczny autor słowiańskiego thumaczenia kroniki Symeona Logotety / Kontynuacji Jerzego Mnicha zmienił natomiast przekaz źródła, stwierdzając, iż bułgarska władczyni przybyła nad Bosfor z trzema synami (съ тримы сновы). Być może miał tu na myśli Borysa II, Romana oraz zagadkowego Plenimira, którego imię pojawia się tylko w jednym zabytku - części laudacyjnej Synodykonu cara Borita (XIII w.).

${ }^{39}$ Krzysztof Lekapen zmarł w 931 roku. Wzmianka o wizytach Marii w Konstantynopolu została przez dziejopisów bizantyńskich (kontynuatora kroniki Jerzego Mnicha, Symeona Logotetę oraz autora Kontynuacji Teofanesa) zamieszczona między informacją o wyniesieniu Teofilakta Lekapena do godności patriarchy Konstantynopola (luty 933 r.) a zapisem o ślubie jego brata Stefana i relacją na temat pierwszego najazdu Węgrów (kwiecień 934 r.). Ostatnią podróż bułgarskiej carycy nad Bosfor należałoby zatem datować na przełom 933/934 roku. 
Каждан А.П. 1959, Хроника Симеона Логофета, Византийский Временник, 15, s. 125-143.

Клосс Б.М. 1972, К вопросу о происхождении Еллинского летописиа второго вида, Труды Отдела древнерусской литературы, 27, s. 370-379.

Колесов В.В. 2004, Заметки о языке Летописиа Еллинского и Римского второй редакции (К вопросу о месте и времени составления), Труды Отдела древнерусской литературы, 55, s. 91-97.

Лихачев Д.С. 1948, Еллинский летописеи второго вида и правительственные круги Москвы конца $X V$ в., Труды Отдела древнерусской литературы, 6, s. 100-110.

Матвеенко В., Щеголева Л. 2000, Временник Георгия Монаха (Хроника Георгия Амартола). Русский текст, комментарий, указатели, Москва, Издательство „Богородский печатник”.

Мещерский Н.А. 1978, Источники и состав древней славяно-русской переводной письменности $I X-X V$ вв., Ленинград, Издательство ЛГУ.

Рыков Ю.Д. 2004, Новонайденный фрагмент Летописиа Еллинского и Римского второй редакиии, Труды Отдела древнерусской литературы, 55, s. 71-81.

Славова Т. 2010, Владетел и администрация в ранносредновековна България. Филологически аспекти, София, Издателство ПАМ Пъблишинг Къмпани.

Творогов О.В. 1975, Древнерусские хронографы, Ленинград, Издательство „Наука”.

- 1987, Хроника Георгия Амартола, w: Д.С. Лихачев, red., Словарь книжников и книжности Древней Руси (XI - первая половина XIV в.), Ленинград, Издательство „Наука”, s. 469-470.

- 1989, Летописеи Еллинский и Римский, w: Д.С. Лихачев, red., Словарь книжников и книжности Древней Руси (вторая половина XIV-XVIв.), t. 2, Ленинград, Издательство „Наука”, s. $18-20$.

- 1999, Летописеи Еллинский и Римский, t. I, Текст, Санкт-Петербург, Издательство „Дмитрий Буланин".

- 2001, Летописеи Еллинский и Римский: текстологические проблемы, Труды Отдела древнерусской литературы, 52, s. 47-78. 